\title{
Does tree-ring formation follow leaf phenology in Pedunculate oak (Quercus robur L.)?
}

\author{
Radosław Puchałka1 ${ }^{1}$ (D) Marcin Koprowski ${ }^{1} \cdot$ Jožica Gričar $^{2} \cdot$ Rajmund Przybylak $^{3}$
}

Received: 18 July 2016/Revised: 3 January 2017/Accepted: 18 January 2017/Published online: 4 February 2017

(C) The Author(s) 2017. This article is published with open access at Springerlink.com

\begin{abstract}
We monitored leaf phenology and xylogenesis of 12 Pedunculate oaks in northern Poland in 2014. We hypothesized that the individual trees, which differed in size, age and habitat (tree stand or gap), also diverged in terms of the seasonal patterns of leaf phenology and xylogenesis. The samples used for wood formation observations were collected most frequently during the early leaf phenophases (from March to end of June). The transverse sections of the cambial region were cut with a sledge microtome. We counted the number of cambial cells, measured the width of xylem increment and assessed the timing of xylogenesis and earlywood-vessel formation. We found significant differences in leaf phenology and timing of xylogenesis among individual trees. The smallest differences in wood formation among the trees were observed at the beginning of the vegetation season when the first earlywood vessels were detected (9 days). The dates of completion of the first tangential row of earlywood vessels varied by up to 30 days, while for the completion of the entire earlywood dates varied by up to 32 days. The highest productivity of cambial cells (13 cell layers) was observed around the time of bud swelling at mid-April. In the last
\end{abstract}

Communicated by Rainer Matyssek.

Radosław Puchałka

puchalka@umk.pl

1 Chair of Ecology and Biogeography, Faculty of Biology and Environment Protection, Nicolaus Copernicus University, Lwowska 1, 87-100 Toruń, Poland

2 Department of Yield and Silviculture, Slovenian Forestry Institute, Vecna pot 2, 1000 Ljubljana, Slovenia

3 Department of Meteorology and Climatology, Faculty of Earth Sciences, Nicolaus Copernicus University, Lwowska 1, 87-100 Toruń, Poland days of April, the number of cambial cell layers decreased and subsequently increased again when the leaves were nearly fully expanded at the end of May. To summarize, we observed a high seasonal variability in the number of cambial cell layers. Differences in the time of cessation of cambial activity and xylogenesis amounted to 1 month. We conclude that: (1) oak tree-ring widths and earlywoodvessel sizes and numbers may not be sensitive indicators for early spring temperature and spring defoliation; (2) the missing association between leaf phenophases and xylogenesis as well as the phenological variability may be the reasons for the lack of a clear climatic effect on the abovementioned parameters.

Keywords Dendroecology · Phenological variability · Xylogenesis · Earlywood vessels

\section{Introduction}

Pedunculate oak (Quercus robur L.) is one of the most widely distributed tree species in Europe. It occurs in highly different climatic conditions, excluding the Arctic, steppe areas and high mountains (Jones 1959; Boratyński et al. 2006). This species is tolerant to differing soil humidity, fertility and acidity. Pedunculate oak is an important component of vegetation types such as mixed coniferous forests, thermophilous and acidophilous oak forests, forest steppes, deciduous mixed forests and riparian forests (Ellenberg 1988; Danielewicz and Pawlaczyk 2006; Stoyko 2009). Due to its high quality of wood, it is one of the most important species in managed forests in Europe (Bugała 2006).

In recent years, an oak decline has been observed in many areas in Europe, mostly due to changes in the 
climatic and hydrological conditions (Führer 1998; Klimo and Hager 2001; Di Filippo et al. 2010; Doležal et al. 2010; Matisons et al. 2013; Sohar et al. 2013). On the other hand, Tulik and Bijak (2016) found a less significant effect of climate on oak decline. In declined oaks, repeated ecophysiological stress resulted in a decrease in the earlywood-vessel diameter and consequently in the reduction of the hydraulic conductivity (Tulik 2014). Smaller earlywood vessels can also be produced as a result of unsuitable weather conditions in the previous summer or low temperatures at the end of winter and in early spring (Garcia-González and Eckstein 2003; Fonti and GarciaGonzález 2008; González-González et al. 2013a, b) or flooding (George et al. 2002; Gričar et al. 2013). In northcentral Poland in 2007 and 2011, late spring frost, which completely damaged the expanding leaves of Pedunculate oaks, did not affect the earlywood-vessel number and size and tree-ring width (Puchałka et al. 2016). This suggests that the population was well adapted to spring defoliation or individuals were in different stages of wood formation and their reaction to late spring frost may differ (Puchałka et al. 2016).

To explain why defoliation did not affect the anatomy of tree rings, the aim of our work was to study seasonal relationships between leaf phenology and xylogenesis of Pedunculate oak differing in size, age and habitat (tree stand or gap) in northern Poland in 2014. Cambial activity and leaf phenology of Pedunculate oak were investigated in detail by other authors also in relation to physiological and meteorological conditions (e.g. Żelawski 1954; Ermich 1959; Michalski and Krzyśko 1970). Many such studies have focused on the ecological and silvicultural importance of the variability of leaf phenology and cambial activity of this species (e.g. Vikhrov 1954; Rubtsov and Utkina 2008; Wesołowski and Rowiński 2008). According to Pukacka (2006), cambial reactivation and first earlywood-vessel formation in oak occur about 2-3 weeks before bud burst, and earlywood is completed before full leaf expansion. However, a recent study on Pedunculate oak showed that vessel development and leaf phenophases are not strictly correlated (Sass-Klaassen et al. 2011). Based on the previous studies, we hypothesized that the trees, which differ in size, age and habitat, may diverge in terms of the seasonal patterns of leaf phenology and xylogenesis.

\section{Materials and methods}

\section{Study site and tree selection}

The monitoring was conducted on 12 Pedunculate oaks (Quercus robur L.) in north Poland in the north-central part of its distribution (Fig. 1). The trees grow on sandy soil in a 100-year-old mixed oak-pine forest $\left[18^{\circ} 34^{\prime} 26.63^{\prime \prime} \mathrm{E}\right.$; $\left.18^{\circ} 34^{\prime} 26.63^{\prime \prime} \mathrm{E}\right]$ about $500 \mathrm{~m}$ from the Nicolaus Copernicus University Weather Station. We selected healthy trees without pathological symptoms on their trunk and in their crown. Eight trees grow in a closed tree stand and 4 in a gap of about $20 \mathrm{~m}$ in diameter. Characteristics of individual trees were measured (perimeter and height), and they were marked so that they could be identified for subsequent re-coring.

Their age was determined after cross-dating the tree-ring series with a regional oak chronology (Puchałka et al. 2016). Nine trees were co-dominant and three subdominant, and they ranged from 7 to $14 \mathrm{~m}$ in height and were from 17 to 62 years old. One co-dominant tree and all subdominant oaks grew in gaps, and the other eight codominant trees in the closed canopy.

\section{Leaf phenophases observation and core sampling}

The field work was conducted in 2014. The cores, containing bark, cambium and outer xylem, were collected in helical order at $120-140 \mathrm{~cm}$ above the ground with a 5-mm increment borer. The first samples were collected on March 10th. From April 2 to May 26, trees were cored at 5-9 days intervals, and from the end of May until October 15 at 7-27 days intervals. In total, 17 samples were collected from each tree. These cores were placed in distilled water and ethanol (1:1) and stored in a refrigerator at $5{ }^{\circ} \mathrm{C}$.

Leaf phenophases were observed from March to the end of June in the upper part of the crown using binoculars and documented with a Canon $40 \mathrm{~d}$ digital camera. We adopted the classification of leaf phenophases (Fig. 2) from Derory et al. (2006).

\section{Sample preparation, measurement and analysis}

The cores were placed in distilled water for $30 \mathrm{~min}$. They were then clamped on a core holder, and cross sections of $20-25 \mu \mathrm{m}$ in thickness were cut using a sledge microtome MC-2. These cross sections were stained in a safranin and astra blue mixture for the differentiation of xylogenesis between the phases (Wegner et al. 2013), whereby red walls mean lignified walls and blue walls not, or not yet, lignified walls. Next, the sections were mounted using a Heft Histokitt and captured using a MOTICAM 580 digital camera.

The wood anatomical measurements were carried out on calibrated digital images of cross sections using the Motic Images Plus 2.0 software. We measured tree-ring width (TRW) and observed the start of earlywood-vessel formation (SVF), end of the first row of vessel formation (EFRV), end of earlywood formation (EEWF) and end of tree-ring formation (ETRF) (Fig. 3; Table 1). These 


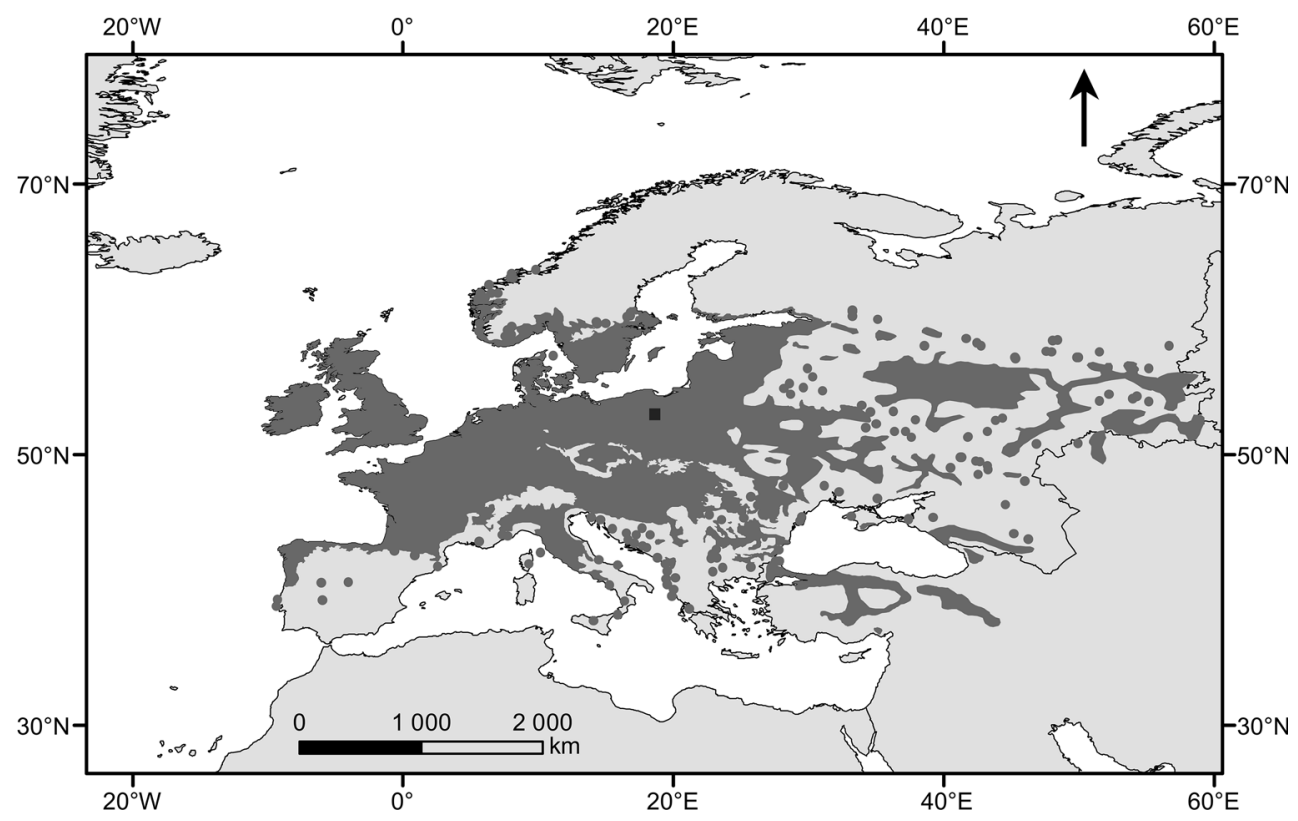

Fig. 1 Distribution of Pedunculate oak in Europe according to EUFORGEN (dark grey areas; black square study site)
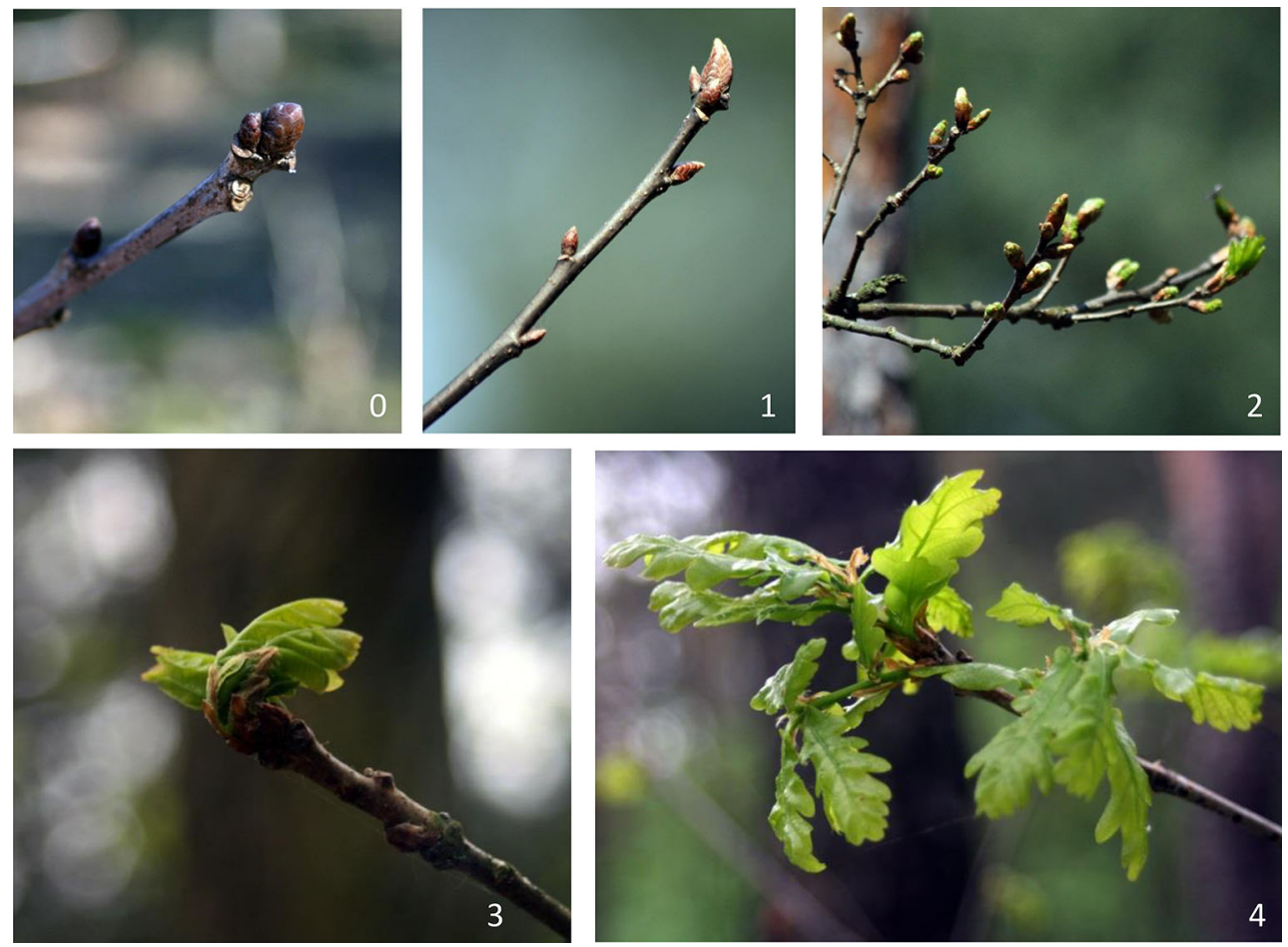

Fig. 2 Leaf phenophases according to Derory et al. (2006): a buds fully closed (dormant stage), b buds swollen, $\mathbf{c}$ buds broken or open, d leaves visible and expanding and $\mathbf{e}$ leaves fully expanded

observations were done on a subarea of $2 \mathrm{~mm}$ of tangential width of each section. The number of cambial cell layers (NCL) was identified based on the blue-coloured cell walls, which are smaller than the phloem cells and have a flattened shape. The reactivation of the cambium was histologically defined by an increased number of cambial cells and the occurrence of newly formed xylem cells in early developmental stages (Prislan et al. 2011). Due to methodological limitations, we were not able to define whether the initial earlywood vessels were formed from un-matured overwintered cells or from newly divided cambial derivatives (Frankenstein et al. 2005). The onset of 


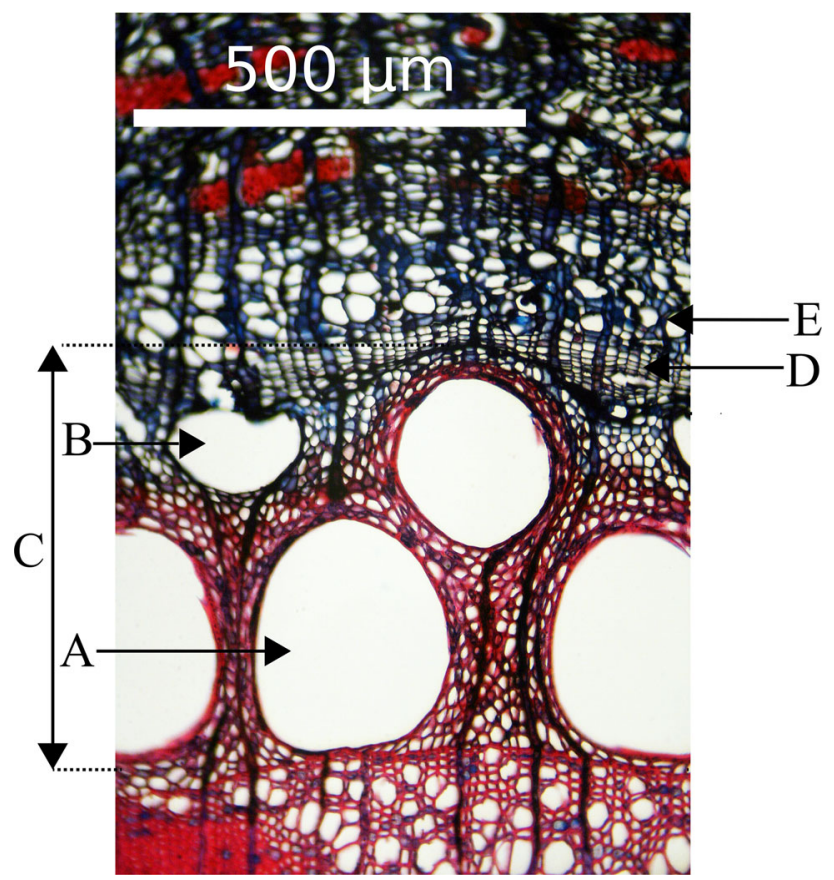

Fig. 3 Cross section through the youngest tree ring on 19 May: Afully developed first row of earlywood vessels, $B$-developing earlywood vessel (next row of vessels), $C$-tree-ring width, $D$-cambial zone, $E$-phloem

xylogenesis was defined by the appearance of earlywood cells adjacent to the cambium. The maturity of the first ring of earlywood vessels was determined by the complete lignification of their walls, indicated by red colour. The end of xylogenesis was identified by the complete lignification of the last-formed latewood cells, indicated by walls stained completely red. The transition from earlywood to latewood was determined when small latewood vessels were no longer arranged in rings, which is characteristic for the large earlywood vessels (Gričar 2010). We subsequently examined the relationship between the onset and end of xylogenesis and leaf phenophases. The climate data were presented for general visualization of the local weather conditions at the study site. The relationships between phases of xylogenesis and leaf phenophases with regard to tree age and size were analysed using correlation coefficients calculated by Gnumeric 1.12.17 and PAST 3.0 software (Hammer et al. 2001).

\section{Results}

Relationships between leaf phenology and xylogenetic phases and the size and age of the trees

A weak positive correlation between the trunk perimeter and the end date of earlywood formation $(r=0.53$, $p=0.074)$ and a weak negative correlation between tree age and the time of bud swelling $(r=-0.52, p=0.086)$ were observed (Table 2). Between tree age and leaf expansion $(r=-0.57, p=0.054)$ and between tree age and the time of full leaf development $(r=-0.65$, $p=0.021)$, the negative correlations were distinctly stronger.

\section{Intra-annual patterns of leaf development and xylogenesis}

In samples collected on March 10, we did not observe any cell-division activity. But on April 2, we noticed an outset of xylogenesis in all trees (Fig. 4) and new earlywood vessels were observed in nine trees (no. 1, 2, 4-9, 12) (Fig. 5). The largest number of cambial cells (up to 13 cell layers) was found between April 11 and 18, when the buds were swollen (Fig. 4). At the end of April, when leaves were nearly fully expanded and the earlywood vessels from the first row were matured, the number of cambial cell layers decreased. Next, a slight increase in the number of cambial cells layers was observed in June. Earlywood was fully formed between the last days of May and the first days of June (no. 1-7, 9, 11, 12), but in two oaks (no. 8, 10) at the end of June (Fig. 5). Tree-ring formation was completed in one individual in the first week of September, whereas in the rest of the trees from the first decade of September to mid-October.

\section{Variability in cambial activity and xylogenesis among individuals}

The differences in the onset of earlywood-vessel formation between trees differed by up to 9 days (Fig. 5). The
Table 1 Measured parameters of tree rings

\begin{tabular}{ll}
\hline Acronym & Tree-ring parameter \\
\hline NCL & Number of cambial cell layers \\
TRW & Tree-ring width \\
SVF & Start of vessel formation \\
EFRV & End of first-row vessel formation (time of first-row vessel lignification) \\
EEWF & End of earlywood formation (time of earlywood-vessel lignification) \\
ETRF & End of tree-ring formation (time of tree-ring lignification)
\end{tabular}


Table 2 Correlations between selected tree parameters and leaf phenophases, and xylogenesis. Numbers in bold shows significant correlation with $p<0.05$

\begin{tabular}{|c|c|c|c|c|c|c|c|c|}
\hline \multirow{2}{*}{$\begin{array}{l}\text { Tree } \\
\text { characteristics }\end{array}$} & \multicolumn{4}{|c|}{ Leaf phenophases } & \multicolumn{4}{|c|}{ Xylogenesis } \\
\hline & 1 & 2 & 3 & 4 & SVF & EFRV & EEWF & ETRF \\
\hline Height & -0.22 & -0.16 & -0.26 & -0.35 & 0.08 & 0.41 & 0.48 & 0.46 \\
\hline Perimeter & -0.17 & -0.11 & -0.28 & -0.39 & 0.28 & 0.25 & 0.53 & 0.49 \\
\hline Age & -0.52 & -0.48 & -0.57 & -0.65 & -0.02 & 0.25 & 0.40 & 0.26 \\
\hline
\end{tabular}

For the leaf phenophases see Fig. 2, for abbreviations see Table 1

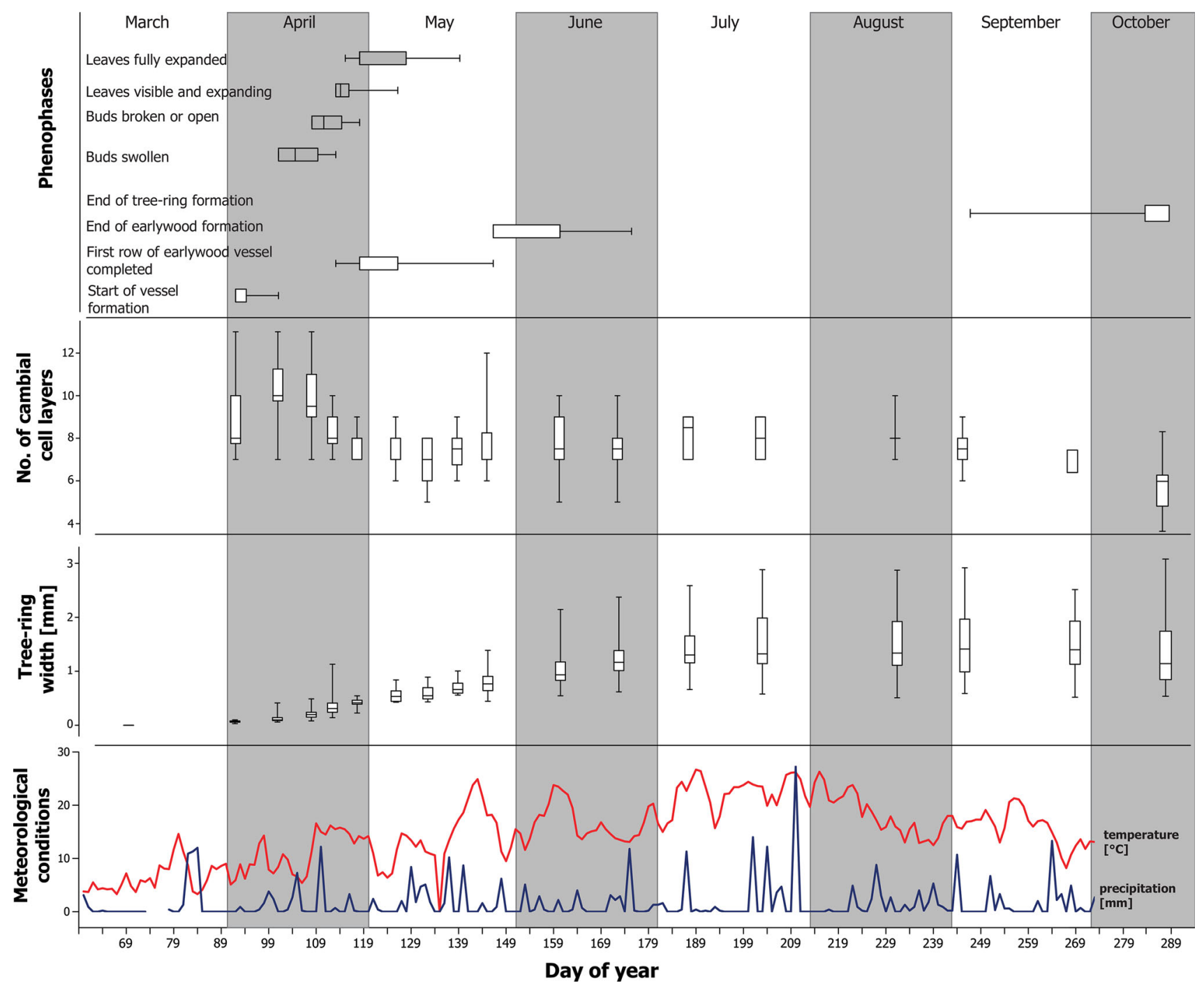

Fig. 4 Relationships between meteorological conditions, leaf phenology and stages of xylogenesis in the study trees in 2014. The whiskers mark the extreme values of measurements, and boxes include $62.26 \%$ of variability

development of the first row of earlywood vessels took 32 days. The end of earlywood formation between trees differed by approximately 1 month. The end of tree-ring formation was observed between September 2 and 24 in three individuals, and between September 24 and 15 October in nine individuals (Fig. 4).

\section{Variability in leaf phenology among individuals}

There was a high variability in the leaf development among the trees (Figs. 4 and 5). Differences between the time of bud swelling was 12 days. In six oaks (no. 1-3, 6, 7, 9), this stage was observed on April 11, in three individuals (no. 8, 


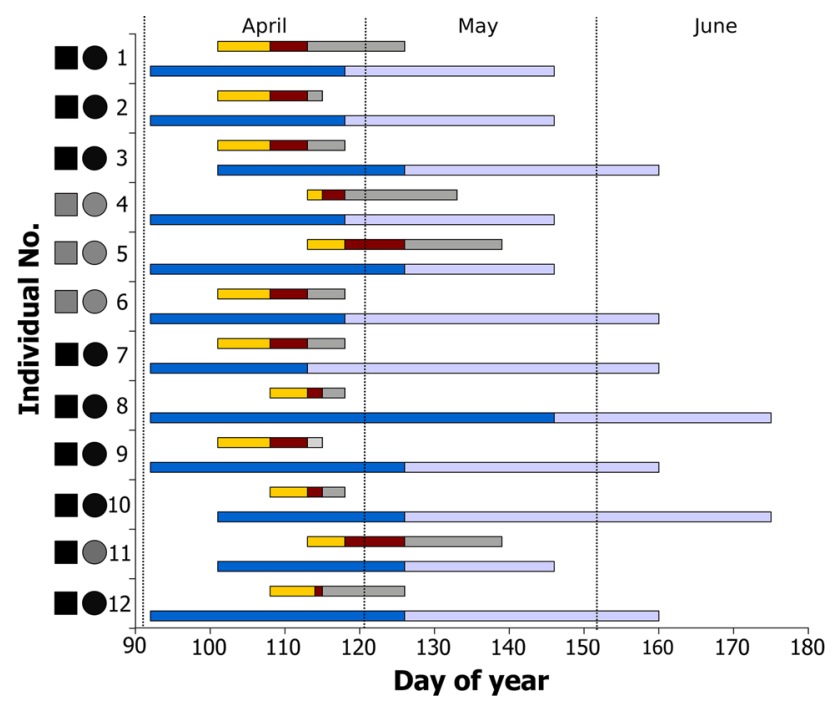

Fig. 5 Differences among individuals in the timing of leaf development and earlywood-vessel formation: orange time between bud swelling and bud break; brown time between bud break and leaf expanding; grey time between leaf expanding and full development; dark blue period of the first row of earlywood-vessel formation; light blue time between the complete development of the first row of earlywood vessels and entire earlywood part; black square codominant tree, grey square subdominant tree; black circle tree stand, grey circle gap in tree stand. (Color figure online)

10, 12), on April 18 in a further three trees (no. 4, 5, 13) and on 23 April in the rest. The time of bud opening (stage 2 ) varied by up to 10 days among the trees. In six oaks (no. 1-3, 6, 7, 9), buds had broken on April 18, in three (no. 8, 10, 12) on April 23, in one (no. 4) on April 25 and in two (no. 5,11 ) on April 28. The time of leaf expansion differed for around 13 days among trees. In six individuals (no. 1-3, 6, 7, 9), leaves expanded on April 23, in three (no. 8, 10, 12) on April 25, in one (no. 4) on April 28 and in two (no. 5,11 ) on May 6.

The time of full leaf expansion differed for around 24 days among trees. In two individuals (no. 2, 9), the leaves were fully expanded on April 25, in five (no. 3, 6-, 10) on April 28, in two (no. 1, 12) on May 6 and in one (no. 4) on May 13 and in two (no. 5, 11) on May 19.

\section{Relationships between leaf phenophases and earlywood-vessel formation}

The leaf development and earlywood-vessel formation proceeded asynchronously (Fig. 5). In three trees (no. 4, 5, 11) in the forest gap, leaves expanded later than in trees growing in a closed canopy and one oak (no. 6) in gap. In one oak (no. 5), the development of the first row of earlywood vessels was completed before bud break in the upper part of the crown. Furthermore, in three trees (no. 4, $7,11)$ the first row of earlywood vessels was completely developed during the time of bud break and leaf expansion, in another three oaks (no. 1, 6, 12) before full leaf development, and in the remaining oaks when the leaves were fully expanded. All earlywood cells were fully formed in all individuals from 6 to 57 days after full leaf expansion. A negative correlation existed between the end of earlywood-vessel formation and the time when the leaves were fully expanded $(r=-0.6, p<0.05)$.

\section{Discussion}

\section{Relationships between tree age, tree size and leaf phenology}

Contrary to our hypothesis, we have not found any clear relationships between age, and size of the trees, habitat and phenology. The correlation coefficient between these parameters suggests that young trees develop leaves later (Table 2). Opposite phenological patterns were observed in Acer mono and Fagus sylvatica, where young trees flush earlier, in order to better use the light before being shaded by mature trees (Dzwonko 1990; Seiwa 1999). On the other hand, studies on several species in seasonally dry tropic climates show that the smallest individuals flush later than mature trees, as they have no access to water in the deeper layers of the soil (Sayer and Newbery 2003).

Pedunculate oak is a species with a broad ecological niche growing in different hydrological conditions (Ellenberg et al. 1992; Danielewicz and Pawlaczyk 2006; Matuszkiewicz 2008; Stoyko 2009). We suppose that the phenological patterns of this species can differ in, for example, hygrophilous riparian forests and dry forest steppe. On the other hand, the lack of clear relationships between age, size, position in the stand and time of leaf expansion suggests that phenological variability in similar soil and hydrological conditions may have a genetic background (Chokheli et al. 2016).

\section{Xylogenesis during the 2014 growing season}

In $75 \%$ of the studied oaks, the first earlywood vessels were detected on April 2 (Figs. 4, 5). This is about 1 month earlier than in the Puszcza Niepołomicka forest in southern Poland with somewhat colder winters (Ermich 1959). Furthermore, a later cambial reactivation in Pedunculate oak, in the second half of April and the beginning of May, was observed in central Germany, Denmark and eastern Europe (Vikhrov 1954; Pukacka 2006). The date of cambial reactivation, which is determined by thermal conditions in early spring, can vary a lot in oak trees (Żelawski 1954; Ermich 1959; Batos et al. 2012). This relationship was confirmed by the research on cambial activity in $Q$. 
petraea (Akkemik et al. 2006), where the difference in dormancy breaking between two vegetation seasons was about 1 month. In the time of the highest divisional activity at the beginning of the vegetation season, 12-13 cambial cell layers were observed in Pedunculate oak (GonzálezGonzález et al. 2013a), and in 9-11 cell layers in sessile oak (Gričar 2008; 2010). In the study trees, we observed 7-13 cambial cell layers when the first row of earlywood vessels was formed before bud break (Fig. 4). The differences in the number of cell layers in the cambium were bigger than in oaks in the Iberian Peninsula (GonzálezGonzález et al. 2013a). The differences in age and size among individuals (Table 1) were likely reasons for a higher variability in cambial activity in our study trees. In addition, we observed a higher variability in the number of cambial cells later in the growing season than other authors (Gričar 2008, 2010; González-González et al. 2013a). A decrease in the number of cambial cell layers in May (Fig. 4) could be due to a decreasing amount of carbohydrates that have been allocated to xylem growth and leaf development (Michelot et al. 2012). At the end of September, the latest formed xylem cells were still developing in most individuals, and the number of cambial cells decreased to 7-8 layers. In the Atlantic region of Spain, such values were reported for the dormant cambium in Pedunculate oak (González-González et al. 2013a). In our study, the number of cambial cells varied from 5 to 6 layers and tree-rings were completed in mid-October in all study trees. In comparison with other studies, xylogenesis started about 2-3 weeks earlier and concluded 2-3 weeks later than on other sites in Poland (Pukacka 2006). This suggests that xylogenesis monitoring over several growing seasons is needed to understand growth patterns of Pedunculate oak at the selected location better, and assess its performance during climate change.

\section{Relationships between leaf phenology and earlywood-vessel formation}

Radial growth of deciduous trees in temperate climates stops in autumn and resumes in spring with the opening of new leaves; however, these two processes are not necessarily synchronized (e.g. Suzuki et al. 1996). In Pedunculate oak, leaf phenology and intra-annual dynamic of xylem formation have often been investigated in different locations in Europe (Ermich 1959; Kitin 1992; SassKlaassen et al. 2011; González-González et al. 2013a; Pérez-de-Lis et al. 2015). According to the literature, earlywood vessels in oak are nearly fully completed before full leaf expansion (Guzicka and Hejnowicz 2006; Pukacka 2006). Some studies showed that characteristics of earlywood vessels, such as their size and number, conveyed information on winter and early spring meteorological conditions (Garcia-González and Eckstein 2003; GarciaGonzález and Fonti 2006, 2007; Fonti and Garcia-González 2008; González-González et al. 2013a; Kniesel et al. 2015). On the other hand, other studies did not detect variation in earlywood-vessel size and number, or in treering width, in response to defoliation caused by late spring frost (Puchałka et al. 2016).

In our study, we did not observe any clear relationship between earlywood-vessel formation and leaf development (Fig. 5). The differences in the time of first earlywoodvessel detection and bud break ranged from 0 to 21 days. Differences were also observed in the time of maturation of the first row of earlywood vessels and the entire earlywood part and leaf phenophases (Fig. 5). This suggests that these two processes are under the control of different internal and external factors. In Pedunculate oak, as in other ring-porous species, earlywood-vessel formation begins before bud break (Guzicka and Hejnowicz 2006). It is considered that the assimilates from the previous vegetation period are used for earlywood formation and that latewood is produced from assimilates in the current season (Ermich 1959; Pukacka 2006). Research on oak in the Netherlands shows that earlywood-vessel formation started later than suggested by Pukacka (2006) and that leaf expansion and treering formation are not strictly inter-dependent processes. Moreover, by the time of full leaf expansion in oak, on average $80 \%$ of the earlywood vessels were completely formed, while in ash all vessels were fully developed (SassKlaassen et al. 2011). In ash by around April 20th, some large earlywood vessels had already formed (Frankenstein et al. 2005). Generally, in ring-porous trees, the first earlywood vessels are formed 2-6 weeks before bud break (Suzuki et al. 1996; Kudo et al. 2015), and it is also worth emphasizing that the lignification of the first-formed vessels in stems was observed from 2 weeks before, up to 4 weeks after, leaf appearance (Takahashi et al. 2013). Thus, the timing of leaf and growth phenologies is species specific, leading to differences in carbon allocation (e.g. Suzuki et al. 1996; Takahashi et al. 2013).

\section{Phenological variability and its ecological significance}

High phenological variability among the study trees (Fig. 5) may be an adaptation of local populations to different stress factors. According to many studies, the phenological variability in this species has an important adaptive significance to abiotic and biotic factors (e.g. Vikhrov 1954; Rubtsov and Utkina 2008; Wesołowski and Rowiński 2008). The highest phenological variability in the natural populations is observed in the eastern European part of the distribution range of this species (e.g. Jones 1959; Rubtsov and Utkina 2008). Between early- and late- 
flushing trees, differences in phenology reach up to 4-5 weeks, similar to populations where both phenoforms (Q. robur fo. praecox and $Q$. robur fo. tardiflora) co-occur (Vikhrov 1954; Rubtsov and Utkina 2008; Wesołowski and Rowiński 2008). They are partially separated in gene flow by differing flowering times (Wesołowski and Rowiński 2008; Chokheli et al. 2016).

The discrepancy in leaf phenology among our study trees reached up to 24 days (Figs. 4, 5) which is comparable with differences observed in mixed populations where early and late oaks co-occur (Kitin 1992; Wesołowski and Rowiński 2008; Vikhrov 1954; Rubtsov and Utkina 2008). In the subsequent years, 2015 and 2016, the time of leaf expansion in the observed oaks was similar to that in 2014 (R. Puchałka and M. Koprowski, field observation). Moreover, we observed trees flushing earlier or later than our study trees. The differences in leaf expansion reached up to 4-5 weeks (field observation). Thus, we can suppose that the studied population can include individuals of both phenoforms. The occurrence of early- and late-flushing forms of Pedunculate oak in Poland is poorly known. They were reported only from eastern Poland in Białowieża National Park (Wesołowski and Rowiński 2008).

The phenological variability in Pedunculate oak indicates an adaptation of this species to different environmental conditions. Early-flushing oak is better adapted to summer drought than late-flushing oak, but early-flushing trees are more threatened by spring frosts and insect outbreak that cause damage to leaves (Vikhrov 1954; Rubtsov and Utkina 2008; Wesołowski and Rowiński 2008). On the contrary, late-flushing oaks are more resistant to lower temperatures in early spring, and defoliation by insects and fungi, but they are more vulnerable to summer drought (Vikhrov 1954; Rubtsov and Utkina 2008; Dantec et al. 2015; Koval and Kostyashkin 2015). Both phenoforms have different preferences in soil conditions, and an improper selection of saplings in the forest may be one of the causes for oak decline (Batos et al. 2014).

According to Koval and Kostyashkin (2015), Pedunculate oak populations in the eastern Ukraine usually contain a few per cent of early-flushing and late-flushing trees. This suggests that these populations may be under disruptive selection to different stress factors. The selective role of winter temperature extremes, summer drought and insect outbreak in oak decline was confirmed by studies in Czechia and Russia where these factors are causes of oak decline (Rubtsov and Utkina 2008; Doležal et al. 2010). According to studies in eastern Europe early- and lateflushing oaks have similar balances of timber growth, but increments in early-flushing oaks are less regular. This is a result of frequent spring defoliation of early-flushing trees, and a stronger resistance to winter and early spring temperatures in late-flushing oaks (Koval and Kostyashkin
2015; Vikhrov 1954). Therefore, we assume that due to the high phenological variability (Figs. 4, 5), the study trees may have reacted differently to late spring frost. Hence, we suppose that the differences in phenology probably constitute the cause for the lack of a climatic signal in 2007 and 2011 in our study trees (Puchałka et al. 2016).

Interestingly, the differences in early spring in the dates of the first earlywood-vessel formation amounted to several days, and in the timing of bud break to 12 days, and these differences in leaf and xylogenesis phases increased during the vegetation season (Figs. 4, 5). The discrepancy for the full leaf expansion among trees was about 24, 32 days for the time of maturation of the first row of earlywood vessels, about 30 days for the end of earlywood formation and for stopping xylogenesis. This suggests that the response to early spring stress, such as defoliation, should be more homogeneous than in factors affecting in late spring and summer.

\section{Conclusions}

For the 12 study trees, strong individual leaf-development and xylem-formation patterns prevail, resulting in a lack of a homogenous climatic signal or a clear effect of tree age and height. This may be linked to the large genetic variability of oak in Poland, which originates from three maternal lineages: Balkan, Apennine and Iberian (Dering et al. 2008). The genetic variability of oaks in relation to leaf phenology and wood formation will therefore be our next focus of research. In our opinion, a clear differentiation of eastern European oaks in early-flushing oaks $(Q$. robur fo. praecox) and late-flushing oaks ( $Q$. robur fo. tardiflora) (Vikhrov 1954), and lack of the phenoform observations in western Europe, may be in line with different maternal lineages. Differences in the resistance to early spring temperature, summer drought and insect outbreaks between early- and late-flushing trees may be important for future forest management also in the light of the anticipated global warming.

Acknowledgements This research is linked to activities conducted within the COST FP1106 network. Jožica Gričar acknowledges support from a Research Fellowship within the project "Enhancing Educational Potential of Nicolaus Copernicus University in the Disciplines of Mathematical and Natural Sciences" (Project No POKL.04.01.01-00-081/10). This paper is part of the habilitation thesis of Dr Radosław Puchałka. We would like to thank the two anonymous reviewers for their valuable suggestions and comments. We also thank Martin Bridge for language correction. R.P. and M.K. received support by the UMK institutional research funding (to the Chair of Ecology and Biogeography).

Author contributions RPu contributed to conception and design, field and laboratory work, statistical analysis; interpretation of results, writing the article; MK contributed to field work, statistical analysis 
and interpretation, writing the article; JG contributed to analysis and interpretation, writing the article; and RPr contributed to preparation of meteorological data and final approval of the article.

\section{Compliance with ethical standards}

Conflict of interest The authors declare that they have no conflict of interest.

Open Access This article is distributed under the terms of the Creative Commons Attribution 4.0 International License (http://creative commons.org/licenses/by/4.0/), which permits unrestricted use, distribution, and reproduction in any medium, provided you give appropriate credit to the original author(s) and the source, provide a link to the Creative Commons license, and indicate if changes were made.

\section{References}

Akkemik Ü, Yilmaz HÇ, Sevgi O (2006) Cambial activity of the sessile oak (Quercus petraea) in Belgrade forest, Istanbul. Turkish J Agric For 30:429-438

Batos B, Miljković D, Ninić-Todorović J (2012) Length of vegetation period as parameter of common oak (Quercus robur L.) phenological variability. Genetika 44:139-152. doi:10.2298/ GENSR1201139B

Batos B, Šešlija Jovanović D, Miljković D (2014) Spatial and temporal variability of flowering in the pedunculate oak (Quercus robur L.). Šumarski List 7-8:371-379

Boratyński A, Boratyńska K, Filipiak M (2006) Systematyka i rozmieszczenie. In: Bugała W (ed) Dęby. Quercus robur L., Quercus petraea Liebl. nasze drzewa leśne. vol 11. Polska Akademia Nauk. Instytut Dendrologii, Poznań-Kórnik, pp 85-114

Bugała W (ed) (2006) Dęby. Quercus robur L., Quercus petraea (Matt.) Liebl. Nasze Drzewa Leśne. vol 11. Polska Akademia Nauk. Instytut Dendrologii, Poznań-Kórnik

Chokheli V, Kozlovsky B, Sereda M et al (2016) Preliminary comparative analysis of phenological varieties of Quercus robur by ISSR-markers. J Bot. doi:10.1155/2016/7910451

Danielewicz W, Pawlaczyk P (2006) Rola dębów w strukturze i funkcjonowaniu fitocenoz. In: Bugała W (ed) Dęby. Quercus robur L., Quercus petraea Liebl. Nasze drzewa leśne. vol 11. Polska Akademia Nauk. Instytut Dendrologii, Poznań-Kórnik, pp 474-564

Dantec CF, Ducasse H, Capdevielle X et al (2015) Escape of spring frost and disease through phenological variations in oak populations along elevation gradients. J Ecol 103:1044-1056. doi:10.1111/1365-2745.12403

Dering M, Lewandowski A, Ufnalski K, Kędzierska A (2008) How far to the east was the migration of white oaks from the Iberian refugium? Silva Fenn 42:327-335

Derory J, Léger P, Garcia V et al (2006) Transcriptome analysis of bud burst in sessile oak (Quercus petraea). New Phytol 170:723-738. doi:10.1111/j.1469-8137.2006.01721.x

Di Filippo A, Alessandrini A, Biondi F, Blasi S, Portoghesi L, Piovesan G (2010) Climate change and oak growth decline: dendroecology and stand productivity of a Turkey oak (Quercus cerris L.) old stored coppice in Central Italy. Ann For Sci 67:706. doi:10.1051/forest/2010031

Doležal J, Mazůrek P, Klimešová J (2010) Oak decline in southern Moravia: the association between climate change and early and late wood formation in oaks. Preslia 82:289-306

Dzwonko Z (1990) Ekologia. In: Białobok S (ed) Buk zwyczajny Fagus sylvatica L. Drzewa Leśne. vol 10. PWN, WarszawaPoznań, pp 237-328
Ellenberg H (1988) Vegetation ecology of Central Europe, 4th edn. Cambridge University Press, Cambridge

Ellenberg H, Weber HE, Düll R et al (1992) Zeigerwerte von Pflanzen in Mitteleuropa. Scr Geobot 18:1-258

Ermich K (1959) The investigations of the seasonal course of the diameter growth of Pinus sylvestris L. and Quercus robur L. Acta Soc Bot Pol 28:15-63

Fonti P, Garcia-González I (2008) Earlywood vessel size of oak as a potential proxy for spring precipitation in mesic sites. J Biogeogr 35:2249-2257. doi:10.1111/j.1365-2699.2008.01961.x

Frankenstein C, Eckstein D, Schmitt U (2005) The onset of cambium activity - a matter of agreement? Dendrochronologia 23:57-62. doi:10.1016/j.dendro.2005.07.007

Führer E (1998) Oak decline in central Europe: a synopsis of hypotheses. In: McManus ML, Liebhold AM (eds) Population dynamics, impacts, and integrated management of forest defoliating insects. USDA forest service general technical report NE247, pp 7-24

Garcia-González I, Eckstein D (2003) Climatic signal of earlywood vessels of oak on a maritime site. Tree Physiol 23:497-504

Garcia-González I, Fonti P (2006) Selecting earlywood vessels to maximize their environmental signal. Tree Physiol 26:12891296

Garcia-González I, Fonti P (2007) Ensuring a representative sample of earlywood vessels for dendroecological studies: an example from two ring-porous species. Trees Struct Funct 22:237-244. doi:10.1007/s00468-007-0180-9

González-González BD, Garcia-González I, Vázquez-Ruiz RA (2013a) Comparative cambial dynamics and phenology of Quercus robur L. and Q. pyrenaica Willd. in an Atlantic forest of the northwestern Iberian Peninsula. Trees Struct Funct 27:1571-1585. doi:10.1007/s00468-013-0905-x

González-González BD, Rozas V, Garcia-González I (2013b) Earlywood vessels of the sub-Mediterranean oak Quercus pyrenaica have greater plasticity and sensitivity than those of the temperate Q. petraea at the Atlantic-Mediterranean boundary. Trees Struct Funct 28:237-252. doi:10.1007/s00468-013-0945-2

Gričar J (2008) Xylogenesis dynamics in sessile oak during 2007. Zb Gozd Lesar 86:45-50

Gričar J (2010) Xylem and phloem formation in sessile oak from Slovenia in 2007. Wood Res 55:15-22

Gričar J, De Luis M, Hafner P, Levanič T (2013) Anatomical characteristics and hydrologic signals in tree-rings of oaks (Quercus robur L.). Trees Struct Funct 27:1669-1680. doi:10. 1007/s00468-013-0914-9

Guzicka M, Hejnowicz A (2006) Anatomia i embriologia. In: Bugała W (ed) Dęby. Quercus robur L., Quercus petraea Liebl. nasze drzewa leśne. vol 11. Polska Akademia Nauk. Instytut Dendrologii, Poznań-Kórnik, pp 147-164

Hammer $\varnothing$, Harper DAT, Ryan PD (2001) PAST: paleontological statistics software package for education and data analysis. Paleontol Electron 4:1-9

Jones EW (1959) Biological flora of the British Isles Quercus L. J Ecol 47:169-222

Kitin P (1992) Dynamics of cambial activity in the stem of early- and late-flushing forms of oak (Quercus robur vars. praecox and tardiflora) in the park of freedom. Sofia. Nauk za Gorata 27:3-13

Klimo E, Hager H (2001) The floodplain forests in Europe: current situation and perspectives. Brill, Leiden Boston Köln

Kniesel BM, Günther B, Roloff A, von Arx G (2015) Defining ecologically relevant vessel parameters in Quercus robur L. for use in dendroecology: a pointer year and recovery time case study in Central Germany. Trees Struct Funct 29:1041-1051. doi:10.1007/s00468-015-1183-6

Koval IM, Kostyashkin DC (2015) The influence of climate and recreation on formation of layers of annual wood of early and 
late forms Quercus robur L. in Kharkiv Greenbelt. Sci Bull UNFU 25:52-58

Kudo K, Yasue K, Hosoo Y, Funada R (2015) Relationship between formation of earlywood vessels and leaf phenology in two ringporous hardwoods, Quercus serrata and Robinia pseudoacacia, in early spring. J Wood Sci 61:455-464. doi:10.1007/s10086015-1487-6

Matisons R, Elferts D, Brūmelis G (2013) Possible signs of growth decline of Pedunculate oak in Latvia during 1980-2009 in treering width and vessel size. Balt For 19:137-142

Matuszkiewicz JM (2008) Zespoły leśne Polski. PWN, Warszawa

Michalski L, Krzyśko K (1970) Seasonal changes in the dynamics of auxins and giberellin-like substances during the development of the terminal buds of oak. AUNC Nauk Mat Przyr 13:147-152

Michelot A, Simard S, Rathgeber C et al (2012) Comparing the intraannual wood formation of three European species (Fagus sylvatica, Quercus petraea and Pinus sylvestris) as related to leaf phenology and non-structural carbohydrate dynamics. Tree Physiol 32:1033-1045. doi:10.1093/treephys/tps052

Pérez-de-Lis G, Rossi S, Vázquez-Ruiz RA et al (2015) Do changes in spring phenology affect earlywood vessels? Perspective from the xylogenesis monitoring of two sympatric ring-porous oaks. New Phytol 209:521-530. doi:10.1111/nph.13610

Prislan P, Schmitt U, Koch G et al (2011) Seasonal ultrastructural changes in the cambial zone of beech (Fagus sylvatica) grown at two different altitudes. IAWA J 32:443-459

Puchałka R, Koprowski M, Przybylak J et al (2016) Did the late spring frost in 2007 and 2011 affect tree-ring width and earlywood vessel size in Pedunculate oak (Quercus robur) in northern Poland? Int J Biometeorol 60:1143-1150. doi:10.1007/ s00484-015-1107-6

Pukacka S (2006) Wzrost i rozwój. In: Bugała W (ed) Dęby. Quercus robur L., Quercus petraea Liebl. nasze drzewa leśne. vol 11. Polska Akademia Nauk. Instytut Dendrologii, Poznań-Kórnik, pp 165-303

Rubtsov VV, Utkina IA (2008) Adaptatsionnyye reaktsii duba na defoliatsiyu. M.: Grif i K, Moskva

Sass-Klaassen U, Sabajo CR, den Ouden J (2011) Vessel formation in relation to leaf phenology in Pedunculate oak and European ash. Dendrochronologia 29:171-175. doi:10.1016/j.dendro.2011.01. 002

Sayer EJ, Newbery DM (2003) The role of tree size in the leafing phenology of a seasonally dry tropical forest in Belize, Central
America. J Trop Ecol 19:539-548. doi:10.1017/S02664674030 03596

Seiwa K (1999) Changes in leaf phenology are dependent on tree height in Acer mono, a deciduous broad-leaved tree. Ann Bot 83:355-361. doi:10.1006/anbo.1998.0831

Sohar K, Helama S, Läänelaid A et al (2013) Oak decline in a southern Finnish forest as affected by a drought sequence. Geochronometria 41:92-103. doi:10.2478/s13386-013-0137-2

St George S, Nielsen E, Conciatori F, Tardif J (2002) Trends in Quercus macrocarpa vessel areas and their implications for treering paleoflood studies. Tree-Ring Res 58:3-10

Stoyko SM (2009) Oak forests of the Ukrainian Carpathians: ecological peculiarities, restoration, conservation. Institute of Ecology of the Carpathians, National Academy of Sciences of Ukraine

Suzuki M, Yoda K, Suzuki H (1996) Phenological comparison of the onset of vessel formation between ring- porous and diffuseporous deciduous trees in a Japanese temperate forest. IAWA J 17:431-444. doi:10.1163/22941932-90000641

Takahashi S, Okada N, Nobuchi T (2013) Relationship between the timing of vessel formation and leaf phenology in ten ring-porous and diffuse-porous deciduous tree species. Ecol Res 28:615-624. doi:10.1007/s11284-013-1053-x

Tulik M (2014) The anatomical traits of trunk wood and their relevance to oak (Quercus robur L.) vitality. Eur J For Res 133:845-855. doi:10.1007/s10342-014-0801-y

Tulik M, Bijak S (2016) Are climatic factors responsible for the process of oak decline in Poland? Dendrochronologia 38:18-25. doi:10.1016/j.dendro.2016.02.006

Vikhrov VE (1954) Stroenie i fiziko-mekhanicheskie svoistva drevesiny duba. Izd-vo Akademii nauk SSSR, Moskva

Wegner L, Sass-Klaassen U, Eilmann B, Wilderink E (2013) Microcore processing - a time and efficient protocol. Wageningen University, Wageningen

Wesołowski T, Rowiński P (2008) Late leaf development in pedunculate oak (Quercus robur): an antiherbivore defence? Scand J For Res 23:386-394. doi:10.1080/02827580802419026

Żelawski W (1954) Czynnik termiczny i świetlny w okresie budzenia się pączków drzew na wiosnę. Sylwan 98:483-486 